\title{
Determinants of Sexual Violence in the City of Lubumbashi: Household Survey in Kampemba Health District
}

\author{
Mwarabu Much'apa Bienfait ${ }^{1}$, Ilunga Kandolo Simon ${ }^{1}$, Bady Kabuya Gabin ${ }^{2}$, \\ Katenda Kankokwe Cathy ${ }^{3}$, Malonga Kaj Françoise ${ }^{1,4}$, \\ Kakoma Sakatolo Zambeze Jean-Baptiste ${ }^{1,4}$ \\ ${ }^{1}$ School of Public Health, University of Lubumbashi, Lubumbashi, Democratic Republic of Congo \\ ${ }^{2}$ School of Criminology, University of Lubumbashi, Lubumbashi, Democratic Republic of Congo \\ ${ }^{3}$ Faculty of Psychology and Education Sciences, University of Lubumbashi, Lubumbashi, Democratic Republic of Congo \\ ${ }^{4}$ Faculty of Medicine, University of Lubumbashi, Lubumbashi, Democratic Republic of Congo \\ Email: *silungak@gmail.com
}

How to cite this paper: Bienfait, M.M., Simon, I.K., Gabin, B.K., Cathy, K.K., Françoise, M.K. and Jean-Baptiste, K.S.Z. (2019) Determinants of Sexual Violence in the City of Lubumbashi: Household Survey in Kampemba Health District. Open Access Library Journal, 6: e5572.

https://doi.org/10.4236/oalib.1105572

Received: July 2, 2019

Accepted: July 28, 2019

Published: July 31, 2019

Copyright $\odot 2019$ by author(s) and Open Access Library Inc.

This work is licensed under the Creative Commons Attribution International License (CC BY 4.0).

http://creativecommons.org/licenses/by/4.0/

\begin{abstract}
Introduction: A major impediment to sustainable development, sexual assault imposes exorbitant costs on families, communities and economies. The objective of the study was to identify the determinants of sexual violence in urban areas. Methodology: This is a cross-sectional descriptive study in the form of a survey of 501 households conducted on 17 and 20 May 2018 at Bongonga District in the Kampemba Health District in Lubumbashi. The sampling was proportionally stratified randomly and the sampling rate was 17. Collected by the structured interview technique after obtaining informed consent, the data were analyzed by the SPSS software version 23 . Univariate analyzes, bivariate and multivariate were made. Results: The community prevalence of sexual violence was $31.1 \%$. Almost all of the victims were female (98.0\%). The median age at first sexual experience was 17 years and the mean age was $15.8 \pm 8$ years. Six variables, namely the history of sexual violence during childhood (AOR $=30.295 \%$ CI [10.4 - 87.4], $\mathrm{p}=0.000)$, the feast $(\mathrm{AOR}=4.995 \% \mathrm{CI}[1.2-19.7], \mathrm{p}=0.027)$, mental handicap $(\mathrm{AOR}=$ $0.07995 \%$ CI $[0.02-0.34], \mathrm{p}=0.001)$, sexy clothing $(\mathrm{AOR}=0.1195 \% \mathrm{CI}$ [0.02 - 0.56], $\mathrm{p}=0.008)$, drunkenness ( $\mathrm{AOR}=0.08195 \% \mathrm{CI}[0.02-0.36], \mathrm{p}=$ 0.001 ) and living in a couple ( $\mathrm{AOR}=0.53295 \% \mathrm{CI}$ [0.33 - 0.87], $\mathrm{p}=0.011$ ), have been found to be determinants of sexual violence. Conclusion: Despite their magnitude, sexual violence, whose main determinants are the antecedent of sexual violence during childhood and living together, remains a neglected health problem in the city of Lubumbashi.
\end{abstract}




\section{Subject Areas}

Public Health, Sociology

\section{Keywords}

Determinants, Sexual Violence, Household Survey, Lubumbashi, Kampemba Health District

\section{Introduction}

At the time of the Sustainable Development Goals defined by the United Nations [1], it is still observed on the face of the earth a recrudescent crime on a large scale. Since the second half of the $20^{\text {th }}$ century, this crime is dictated most often by many interests or factors acting in completely different contexts (economic, social, cultural, political or even religious). It is variously called sexual violence, sexual assault or sexual abuse [2]-[9]. This plague can strike any human being, regardless of age, sex or standing [10] [11]. As a major impediment to sustainable development, sexual violence imposes exorbitant costs on families, communities and economies [12].

Sexual violence encompasses all forms of sexual assault against people and can take a variety of forms depending on their nature (insults, caresses, penetration), their frequency (single or repeated in the course of a more or less long period), their intensity (aggressive episode accompanied by torture), their context (ritual, hazing), their environment (school, family, resort, workplace) and the type of relationship between the victim and the perpetrator of the violence (paternal or maternal incest, sexual harassment, authoritative person, spouse, sexual partner ... up to self-inflicted sexual violence from prostitution) [13].

As a major global public health problem of epidemic scale and requiring urgent action, sexual violence must be considered as a scourge to be fought at all costs [14]. Nearly one in four women would be exposed, at some point in their lives, to their partner's sexual violence [15]. But the most recent statistics indicate a prevalence of $35 \%$ [16]. Around the world, 120 million girls (about one in ten girls) have had sexual or other forced sexual acts at some point in their lives. Boys are also at risk [17]. Sexual violence depends on a variety of factors in a wide variety of social, cultural and economic situations [15].

With the Democratic Republic of Congo (DRC) having a poverty rate of around $70 \%$ of its general population [18] [19] [20], sexual violence is still rife despite the existence of a remarkable criminal arsenal [21] [22] [23]. Statistics on this scourge are divergent and unreliable. In addition, there is a paucity of in-depth scientific studies of sexual abuse, although the DRC is a time-stamped "World Capital of Rape" [24].

The purpose of the study was to identify the determinants of sexual violence in urban areas outside of any armed conflict. 


\section{Methodology}

The Sanitary District of Kampemba (that is to say the Kampemba Health Zone, according to the Congolese nomenclature) which served us as a framework of study includes 2 Health Areas (SA) disproportionate in terms of population of responsibility: 46,856 inhabitants for the AS Kabanga and 23,730 inhabitants for the AS Suzanella, the 2 Health Areas forming administratively the Bongonga District [25]. This is a cross-sectional descriptive study in the form of a survey of 501 households, conducted on May 17 and 20, 2018, from 9 am to 4 pm with the assistance of 10 previously trained interviewers. The sampling was proportional random stratified and the probing step was of the order of 17 . Carried out tactfully in an African environment where sex remains notoriously a taboo subject, this victimization survey over the period from 2016 to 2018 targeted both sexes, regardless of age or marital status. After obtaining free and informed consent, the data was collected by the structured interview technique based on a strictly funnel-based questionnaire, entered and encoded with Excel 2016 before being analyzed by SPSS Version 23 (Univariate and bivariate analyses as well as logistic regression).

\section{Results}

\subsection{Community Prevalence of Sexual Violence}

The community prevalence of sexual violence during the period 2016-2018 was around $31.1 \%$ (Figure 1).

\subsection{Types of Sexual Violence}

Table 1 shows that the most prevalent types of sexual violence were, in order of decreasing importance, rape (64.1\%), sexual harassment (29.5\%), indecent assault $(21.2 \%)$, forced pregnancy (20.5\%) and forced marriage (19.9\%), while the incitement of minors to debauchery represented the lowest proportion in the sample (4.5\%)

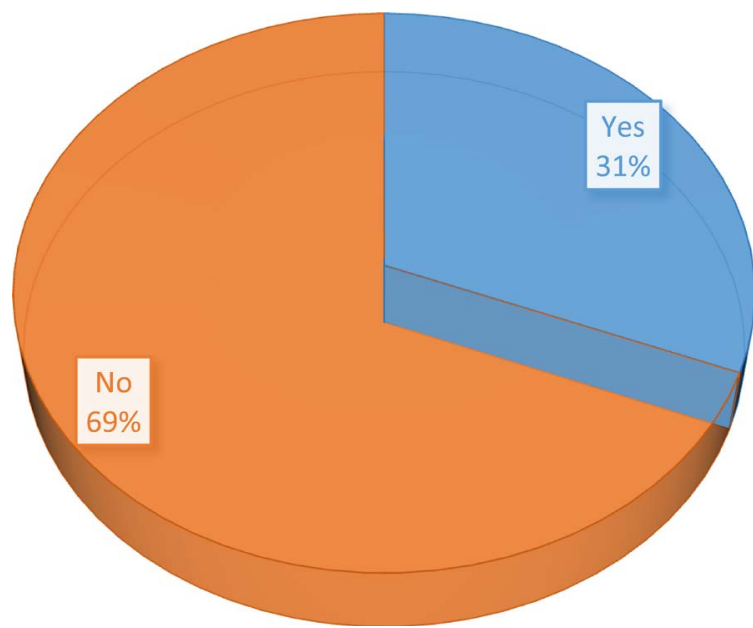

Figure 1. Distribution of respondents according to the occurrence of sexual violence during the period from 2016 to 2018 
Table 1. Distribution of respondents by type of sexual violence.

\begin{tabular}{ccc}
\hline Types of sexual violence & $(\mathrm{N}=156)$ & $(\%)$ \\
Rape & 100 & 64.1 \\
Forced marriage & 31 & 19.9 \\
Forced pregnancy & 32 & 20.5 \\
Incitement of minors to debauchery & 7 & 4.5 \\
Sexual harassment & 46 & 29.5 \\
Molestation & 33 & 21.2 \\
\hline
\end{tabular}

\subsection{History of Sexual Abuse during Childhood}

Forty-four respondents out of $501(8.8 \%)$ reported having been sexually assaulted during childhood (Figure 2).

\subsection{Sex}

Almost all of the interviewees were female, both for the respondents in general and for the victims in particular, namely $99 \%$ (sex ratio between men and women $=0.01)$ and $98 \%$ (sex ratio between men and women $=0.02)$.

\subsection{Age}

Nearly 8 out of 10 respondents were older than or equal to 20 years, i.e. $79.4 \%$ compared to $0.6 \%$ of cases under 10 years of age and $20 \%$ of interviewees whose age ranged from 10 to 19 years. In this series, age 4 and age 76 , the median age was 29 years and the mean age was $31.3 \pm 12.6$ years.

\subsection{Age at First Sexual Intercourse}

The vast majority of respondents had their first sexual intercourse during adolescence, at $88.8 \%$, while the cases that experienced it before the age of 10 constituted a

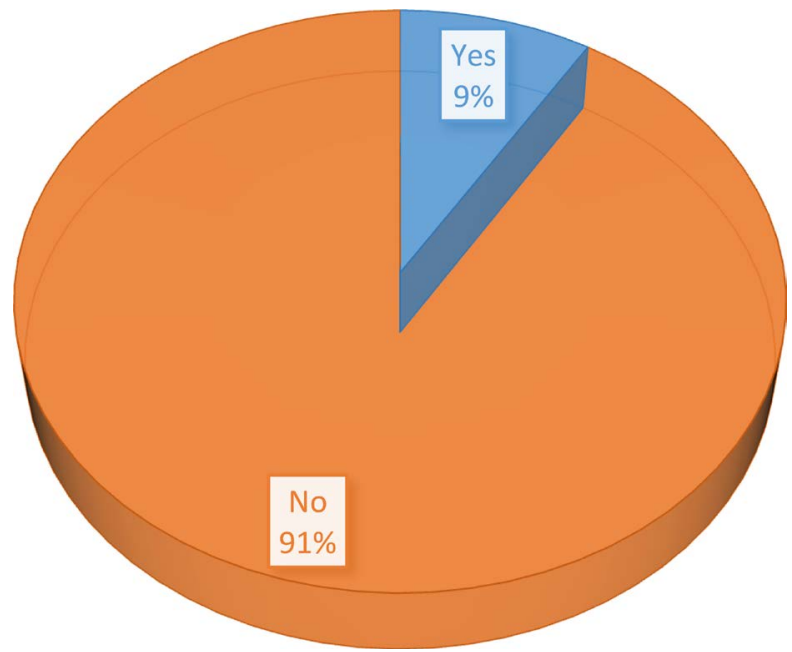

Figure 2. Distribution of respondents according to the history of sexual abuse during childhood. 
very small proportion (1.1\%). The median age at first intercourse was around 17 years and the mean age was $15.8 \pm 8$ years.

\subsection{Educational and Socio-Economic Level}

The majority of respondents were either uneducated $(38.1 \%)$ or at a primary level (45.1\%), with academics being almost rare in our sample (1.6\%). About $63 \%$ of those interviewed were of low socioeconomic status.

\subsection{Factors Associated with Sexual Violence}

Victims who reported the history of childhood sexual abuse were 3 times (88.6\%) more likely than No-affected children (25.6\%). Respondents with a history of sexual abuse during childhood were 22.7 times more likely to be victims of sexual violence than respondents who had not experienced this child sexual abuse, as the difference was very high. Significant $(\mathrm{OR}=22.7[8.7-58.9], \mathrm{p}=$ 0.000).

The association between physical disability and sexual violence was not considered significant $(\mathrm{OR}=1.1[0.43-2.73], \mathrm{p}=0.859)$ while a statistically significant relationship was observed between mental disability and the occurrence of sexual violence ( $\mathrm{OR}=4.2[1.8-9.7], \mathrm{p}=0.000$ ), the risk for exposed individuals being multiplied by approximately 4 .

Respondents living in couples (29.5\%) experienced more sexual violence than those who were outside the conjugal roof $(12.5 \%)$. The association between living with a partner and sexual violence was highly significant, with a risk of being about 3 times higher $(\mathrm{OR}=2.9[1.8-4.6], \mathrm{p}=0.000)$.

Sexually abused drug abused victims were more represented than those without a history of substance abuse (66.7\% versus $17.9 \%)$. However, the association between these two variables (substance abuse and sexual violence) was not significant $(\mathrm{OR}=9.2[0.8-102.5], \mathrm{p}=0.086)$.

The occurrence of sexual assault was more common among those who were drunk (60.9\%) than those who did not show drunkenness (16.1\%). There was a very highly significant association between drunkenness and sexual abuse, with the risk being nearly 8 times higher $(\mathrm{OR}=8.1[3.4-19.4], \mathrm{p}=0.000)$.

Respondents with sexy clothing were about 3 times more sexually abused (72.7\%) than those who were decently dressed (15.7\%). There was a very highly significant association between sexy clothing and sexual abuse, the risk being about 14 times higher $(\mathrm{OR}=14.4$ [5.4 - 37.9], $\mathrm{p}=0.000)$.

Sexually abused respondents at a party accounted for a far greater proportion (60.0\%) than other victims (29.6\%). A highly significant association was found between the variable "feast" and that called "sexual violence", the risk incurred being approximately 4 times higher $(\mathrm{OR}=3.6[1.6-8.1] \mathrm{p}=0.001)$.

\subsection{Determinants of Sexual Violence}

Multivariate analysis of logistic regression data showed that six of the following 
variables were determinants of sexual abuse among victims: the history of childhood sexual abuse $(\mathrm{AOR}=30.295 \% \mathrm{CI}[10.4-87.4], \mathrm{p}=0.000)$ and the feast $(\mathrm{AOR}=$ $4.995 \% \mathrm{CI}[1.2-19.7], \mathrm{p}=0.027)$ and the couple's life (AOR $=0.53295 \% \mathrm{CI}$ [0.33 - 0.87], $\mathrm{p}=0.011)$, sexy clothing $(\mathrm{AOR}=0.1195 \%$ CI $[0.02-0.56], \mathrm{p}=$ $0.008)$, drunkenness (AOR $=0.08195 \%$ CI $[0.02-0.36], \mathrm{p}=0.001)$ and mental handicap $(\mathrm{AOR}=0.07995 \% \mathrm{CI}[0.02-0.34], \mathrm{p}=0.001)$.

\section{Discussion}

In this series, almost all of the respondents were female, both for the respondents in general and for the victims in particular, 99\% (with a male/female sex ratio of 0.01 ) and $98 \%$ respectively. (sex ratio between men and women $=0.02$ ). This corroborates the results of many studies that have confirmed that victims of sexual violence are mainly female as shown by Table 2 [8] [10] [26] [27] [28] [29].

Almost 9 out of $10(88.8 \%)$ had their first sexual intercourse during adolescence, with a median age of 17 and an average age of $15.8 \pm 8$ years. This is almost identical to the results found by the DHS II/DRC that among women aged 25 - 49 in the survey, $24 \%$ had already had sex before reaching age $15,65 \%$ before to reach 18 years, $81 \%$ before reaching 20 years and 25 years exact, almost all women had already had their first sexual intercourse (Table 3). For women aged 25 - 49, the median age at first intercourse is estimated at 16.8 years [18]. According to some authors, the age at first intercourse has fallen sharply by two years: from 20 and a half in 1960 to 18 and a half in 1970 for women, and from 18 to 17 years and a half for men, "unlike the period from the 1980s to the mid-2000s." The median age is estimated around $17^{1 / 2}$ years for young men and women in France, "Sexual initiation is currently" a full experience of adolescence, increasingly disconnected from a conjugal project and a fortiori nuptial [30].

In this study, it was shown that there was a significant association between the occurrence of sexual violence and mental (Table 3 ) disability ( $\mathrm{OR}=4.2[1.8$ 9.7], $\mathrm{p}=0.000$ ), this variable also proved to be a determinant ( $\mathrm{AOR}=0.07995 \%$ CI [0.02 - 0.34], $\mathrm{p}=0.001)$. Fragile by their physical and intellectual difficulties (loss of vision, difficulty hearing, motor restriction, overconfidence in the caregiver, etc.), women with disabilities are more vulnerable to violence, verbal aggression, physical, sexual and psychological [31].

Indeed, women with disabilities experience emotional, physical and sexual

Table 2. Distribution of respondents and victims by gender.

\begin{tabular}{ccccc}
\hline Sex & \multicolumn{3}{c}{$(\%)$} \\
\cline { 2 - 5 } & $\mathrm{N}$ & Victims & \\
\hline Female & 496 & 153 & 99.0 & 98.0 \\
Male & 5 & 3 & 1.0 & 2.0 \\
Total & 501 & 156 & 100.0 & 100.0 \\
\hline
\end{tabular}


Table 3. Distribution of respondents by factors associated with sexual violence.

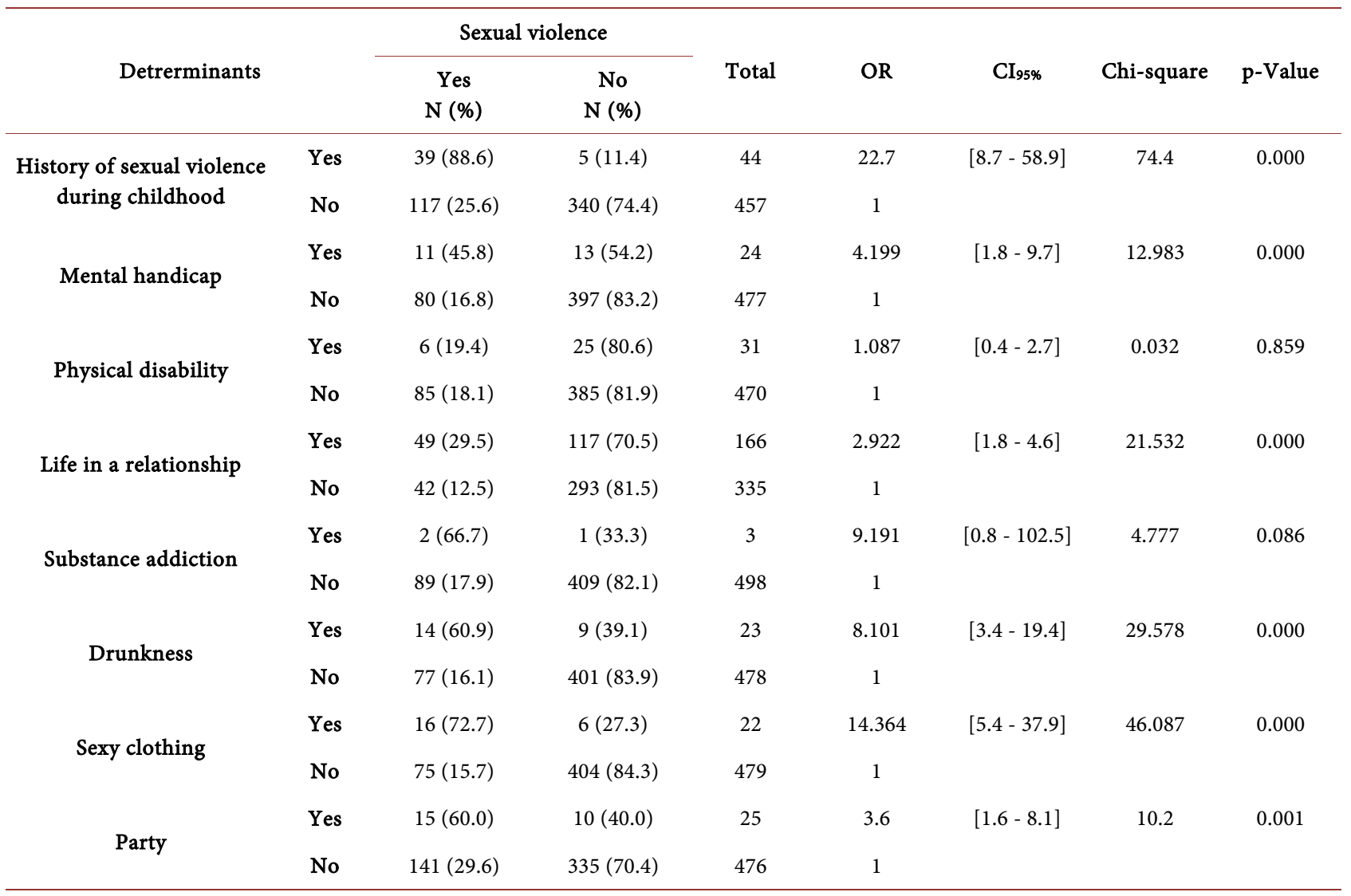

assault by a variety of individuals, including their caregivers, caregivers, health care providers, and family members and strangers [32].

The fact that people with disabilities often live, regardless of their age and despite appearances, in a real emotional desert increases their vulnerability [33].

Interviewees with a history of sexual abuse during childhood accounted for $8.8 \%$ of cases. A highly significant relationship was observed between having been sexually abused during childhood and the occurrence of sexual violence reported in this survey $(\mathrm{OR}=22.7[8.7-58.9] \mathrm{p}=0.000)$ and logistic regression demonstrated that this variable is a determinant of transgressive sexual behaviour in Lubumbashi (AOR $=30.295 \% \mathrm{CI}$ [10.4 - 87.4], $\mathrm{p}=0.000$ ). Many studies have highlighted the trans generational effects of sexual violence (Table 4). Events such as violence, attacks, abuse and rapes that cause fear can have serious long-term psychological consequences [34].

Sexual abuse corresponds much less to sexual disorders than attempts to "defensive solution" vis-à-vis major anxieties about the feeling of identity that are themselves consecutive to fundamental shortcomings of the primary environment during early childhood [35].

The 2014 WHO report indicated that $20 \%$ of women worldwide have experienced sexual abuse in childhood [36].

In France, more than half of the rapes are committed on minors and the "Impact 
Table 4. Determinants of sexual violence.

\begin{tabular}{cccc}
\hline Variables & AOR & CI95\% & p \\
\hline History of sexual violence during childhood & 30.208 & {$[10.436-87.439]$} & 0.000 \\
Party & 4.851 & {$[1.198-19.650]$} & 0.027 \\
Mental handicap & 0.079 & {$[0.019-0.337]$} & 0.001 \\
Life in a relationship & 0.532 & {$[0.326-0.867]$} & 0.011 \\
Intoxication & 0.081 & {$[0.018-0.360]$} & 0.001 \\
Sexy clothing & 0.107 & {$[0.020-0.561]$} & 0.008 \\
\hline
\end{tabular}

of Sexual Violence from Childhood to Adult Adults" survey showed that $81 \%$ of sexual violence starts before the age of 18 [28].

Adverse Childhood Experiences (EIDs), in acronyms or English ACE, have long-term negative effects, leaving significant traces both psychically and physically [37].

Mouchet et al. suggested a link between childhood victimization and adult sexual abuse in perpetrators of sexual violence [38].

The US "Adverse Childhood Experience" study by Felitti and Anda for more than 17,000 people found that 50 years after experiencing severe childhood abuse and neglect, people were exposed to high-risk sexual behaviour. The risk of trans generational effects, i.e. the risk of experiencing violence again or again during his or her life [28].

Subjects living in a conjugal relationship (29.5\%) experienced more sexual abuse than those who were not in a couple (12.5\%) and the association between living with a partner and the occurrence of sexual violence was significant $(\mathrm{OR}=$ 2.9 [1.8 - 4.6], $\mathrm{p}=0.000$ ), the risk was nearly 3 times higher. In addition, logistic regression showed that the variable "living in couples" is a determinant of sexual violence $(\mathrm{AOR}=0.53295 \% \mathrm{CI}[0.33-0.87], \mathrm{p}=0.011$ ). Conjugal life seems indeed perilous as attested by a French ministerial report of the year 2017 according to which 219,000 women majors declared to have been victims of physical and/or sexual violence by their spouse or former spouse over one year, 3 cases on 4 having undergone repeated acts and $80 \%$ of the respondents having been subjected to psychological attacks [39].

Sexually abused drug addicts (66.7\%) accounted for almost four times the number of victims who did not report substance abuse (17.9\%), but the association between these two variables (substance abuse and sexual abuse) was not significant $(\mathrm{OR}=9.2[0.8-102.5], \mathrm{p}=0.086)$, presumably due to the small size of the sample, which contained only 3 out of every 50 drug users. The results would tend to corrobAORte what the Western media reports about the fact that the abuser pours GHB (gamma-hydroxybutyric acid)-commonly called the drug of rape-in the glass of his victim before violating it without his knowledge [40].

Sexual abuse was more common among respondents who were drunk (60.9\%) 
than those who did not show drunkenness (16.1\%) and a very significant association between drunkenness. and sexual abuse was highlighted $(\mathrm{OR}=8.1$ [3.4 19.4], $\mathrm{p}=0.000$ ), drunkenness being here also a determinant ( $\mathrm{AOR}=0.08195 \%$ $\mathrm{CI}[0.02-0], 36], \mathrm{p}=0.001)$. The drunkenness repeated phenomenon is at the origin of both social and health complications ranging from comas and road accidents, to risks of manipulation and physical or sexual violence, as well as to longer term, addiction [41].

Sexually abused respondents at a party accounted for a larger proportion (60.0\%) than other victims (29.6\%). This variable "holiday" was significantly related to the occurrence of sexual abuse $(\mathrm{OR}=3.6[1.6-8.1], \mathrm{p}=0.001)$ and was found to be a determinant of sexual violence in our medium (AOR $=4.995 \% \mathrm{CI}$ [1.2 - 19.7], $\mathrm{p}=0.027)$. This is consistent with a study of 9284 Quebecers working or studying on a university campus where more than one-third (36.9\%) had experienced at least one form of sexual victimization in their community and almost half of these cases would have occurred during a party or other social activity [40].

\section{Conclusions}

This survey of 501 households found a community prevalence of transgressive sexual behavior of $31.1 \%$. Almost all of the victims were female (98\%). At first intercourse, the median age was 17 years and the mean age was $15.8 \pm 8$ years.

Six variables, namely, dating, history of childhood sexual abuse, sexy clothing, party, drunkenness, and mental disability, were clearly determinants of sexual violence, which, despite their scale, constitute a neglected health problem in the city of Lubumbashi.

\section{Conflicts of Interest}

The authors declare no conflicts of interest regarding the publication of this paper.

\section{References}

[1] ONU (2015) Les Objectifs de Développement Durable. New York, 21.

[2] AdN (2016) LOI n²016-444 Visant à renforcer la lutte contre le système prostitutionnel et à accompagner les personnes prostituées. publiée au Journal officiel le 13 avril 2016. Journal Officiel de la République Française, 25.

[3] Présidence/RDC (2006) Loi n 06/018 du 20 juillet 2006 modifiant et complétant le Décret du 30 janvier 1940 portant Code pénal congolais. Journal Officiel de la République, 2-4.

[4] Présidence/France (2019) Code Pénal Français. Legifrance, Paris, France, 393.

[5] Bariéty, A. (2017) Viol, agression sexuelle, harcèlement... quelles lois à l'étranger? Le Figaro, 11-13.

[6] Soumah, M.M., Olendo, G.R. and Ndiaye, M.S.L. (2013) Agressions sexuelles à Port-Gentil. The Pan African Medical Journal, 15, 152.

https://doi.org/10.11604/pamj.2013.15.152.1884 
[7] Adama-hondégla, A.B., Aboubakari, A., FiagNo, K., Augustha, R. and Akpadza, K. (2013) Aspects épidémio-cliniques et prise en charge des agressions sexuelles chez les sujets de sexe féminin à Lomé. Résultats. African Journal of Reproductive Health, 17, 67-72.

[8] WHO (2002) Sexual Violence. In: World Report on Violence and Health, WHO, Geneva, 163-202.

[9] UNHCR (2018) Sexual and Gender Based Violence (SGBV) Prevention and Response. UNHCR Emergency Handbook.

[10] Shahrokh, T. and Edström, J. (2015) Sexual and Gender-Based Violence. In Edström, J., Hassink, A., Shahrokh, T. and Stern, E., Eds., Engendering Men: $A$ CollabAORtive Review of Evidence on Men and Boys in Social Change and Gender Equality, Promundo-US, Sonke Gender Justice and the Institute of Development Studies, Washington DC, 116-137.

https://www.researchgate.net/publication/282007221

[11] Baaz, M.E. and Stern, M. (2018) Curious Erasures: The Sexual in Wartime Sexual Violence. International Feminist Journal of Politics, 20, 295-314. https://doi.org/10.1080/14616742.2018.1459197

[12] Ki-Moon, B. (2016) Rapport de la Journée Internationale pour l'Elimination de la Violence à l'égard des Femmes. New York.

[13] Courtet, P. and Lacambre, M. (2007) Pathologies et Sexualité Pathologies et Sexualité. Montpellier.

[14] WHO (2013) Global and Regional Estimates of Violence against Women: Prevalence and Health Effects of Intimate Partner Violence and No-Partner Sexual Violence. WHO, Geneva.

[15] OMS (2002) Rapport mondial sur la violence et la santé. Editions d. OMS, Genève, 404.

[16] OMS (2015) La violence à l'encontre des femmes: Violence d'un partenaire intime et violence sexuelle à l'encontre des femmes. Aide-mémoire n²39. OMS, Genève.

[17] UNICEF (2015) Cachée sous nos yeux : Une analyse statistique de la violence envers les enfants. In: Données mondiales de P UNICEF 2014, 8.

[18] Ministère du Plan/RDC, MSP/RDC, OMS, PNUD (2014) Deuxième Enquête Démographique et de Santé (EDS-RDC II 2013-2014). MEASURE DHS, ICF International, Rockville, MD, 678.

[19] MSP/RDC (2010) Stratégie de Renforcement du Système de Santé. Deuxième é. Kinshasa, 64.

[20] MSP/RDC (2016) Plan National de Développement Sanitaire 2016-2020: Vers la couverture sanitaire universelle. Kinshasa, 1-97.

[21] Présidence/RDC (2006) Loi $\mathrm{n}^{\circ}$ 06/018 du 20 juillet 2006 modifiant et complétant le Décret du 30 janvier 1940 portant Code pénal congolais. Journal Officiel de la République Démocratique du Congo, 3.

[22] Présidence/RDC (2006) Les lois sur les violences sexuelles. MONUSCO (Mission d'Observatiobn des Nations-Unies pour la Stabilisation eb République Démocratique du Congo), Kinshasa, 24.

[23] Présidence/RDC (2009) LOI n 09/001 du 10 janvier 2009 Portant Protection de l'Enfant, Loi $\mathrm{n}^{\circ}$ 08/011 du 14 juillet 2008 Portant Protection des Droits des Personnes Vivant avec VIH/Sida et des Personnes Affectées, Loi n 06/018 du 20 juillet 2006 modifiant et complétant le Décret du 30 janvier 1940 portant Code Pénal Congolais. Journal Officiel de la République Démocratique du Congo, 1-47. 
[24] ANoyme (2016) Atelier National sur les Statistiques des Violences Sexuelles durant l'année 2015 en République Démocratique du Congo. Kinshasa.

[25] BCZS Kampemba (2018) Plan d'Action Opérationnel 2018 (PAO 2018). Lubumbashi.

[26] Mwarabu, B.M., Kandolo, S.I., Matungulu, C.M. and Kakoma, J.-B.S.Z. (2017) Sexual Violence in Urban Environments: Example in the City of Lubumbashi, Democratic Republic of the Congo. Santé Publique, 29, 125-131.

https://doi.org/10.3917/spub.171.0125

http://www.ncbi.nlm.nih.gov/pubmed/28737319

[27] Duguet, A., Lazimi, G., Hervé, C., Jehel, L., SeNo, J.-L., de Beco, Is., Ducrocq, F., Lopez, G., Piet, E. and Salmonal, M. (2014) Violences sexuelles et autres violences faites aux femmes. In: Stratégies des données pour décider en médecine générale, 262-268.

[28] Salmona, M. (2018) Le livre noir des violences sexuelles. 2ème édition, Editions Dunod, Paris, 30.

[29] Jewkes, R.K., Dunkle, K., Nduna, M. and Shai, N. (2010) Intimate Partner Violence, Relationship Power Inequity, and Incidence of HIV Infection in Young Women in South Africa: A Cohort Study. The Lancet, 376, 41-48. https://doi.org/10.1016/S0140-6736(10)60548-X

[30] Maillochon, F., Ehlinger, V. and Godeau, E. (2016) L'âge "normal" au premier rapport sexuel. In: $A g A O R$, Presses de Sciences Po, Paris, 21. https://doi.org/10.3917/agora.hs01.0037

[31] FDFA Violences envers les femmes handicapées. Paris, 1-53.

[32] Dawn Rafh Canada (2013) Les Femmes en situation de handicap et violence. DisAbled Women's Network, Montreal, 1-5.

[33] Dupont, C. (2007) Violence et handicap. L’Entente, 34.

[34] Chambon, N. (2018) Soigner le traumatisme? Rhizome: Bulletin National Santé Mentale et Précarité, No. 69-70, 40. https://doi.org/10.3917/rhiz.069.0001

[35] Delarue, J., et al. (2018) Auteurs de violences sexuelles: Prévention, évaluation et prise en charge, Rapport de la Commission d'audition du 17 juin 2018. Paris.

[36] Dollinger, M. (2016) Violences sexuelles durant l'enfance: Quelles conséquences sur la sexualité ? Vol. 1. Université de Strasbourg, Strasbourg, 118.

[37] Cirillo, S. (2011) L'enfant abusé devient adulte : Réflexions à partir de plusieurs situations traitées. 26. https://doi.org/10.3917/ctf.046.0139

[38] Mouchet-Mages, S. and Plancade, O. (2018) Traumatisme infantile et adversités dans l'enfance chez les auteurs d'agressions sexuelles. Rhizome: Bulletin national santé mentale et précarité, 3. https://doi.org/10.3917/rhiz.069.0013

[39] Premier Ministre/France (2017) Les violences au sein du couple en France en 2017. 2 .

[40] ANoyme (2017) L’alcool et le sexe. Educ alcoo, Québec, 16.

[41] Ministère de la Santé/France (2008) "Liens entre alcool et violence" les résultats de la première étude française spécifique Conférence de presse Sommaire. Paris, 1-17. 